sum of the 11 other large neutral amino acids also were raised $(P<0.02,<0.001$ and $<0.001$ respectively).

In view of the mode of entry of amino acids into the brain, these data point to a possible source of abnormality in the central nervous system in young adults with Downs syndrome in terms of availability of substrate for protein synthesis.

It is suggested that this aspect of metabolism may merit further investigation both in Downs syndrome and in senile dementia itself.

This research was completed from a Welsh Office grant.

SARAH E. Watkins

Michael A. Clifford

SIMON F. TIDMARSH

VALERIE E. COWIE

DAVID M. SHaW*

University of Wales

College of Medicine

Whitchurch Hospital

Whitchurch, Cardiff CF4 $7 X B$

ERIC Ah-Sing

JOHN W. T. DICKERSON

Division of Nutrition and Food Science

University of Surrey

Guildford GU2 SXH

* External Scientific Staff of $M R C$

References

BURGer, P. C. \& VoGEL, F. S. (1973). The development of pathologic changes of Alzheimer's disease and senile dementia in patients with Down's syndrome. American Journal Psychiatry. 73, 549-576.

Hewitt, K. E., Carter G. \& Jancer J. (1985). Ageing in Down's Syndrome. British Journal of Psychiatry, 147, 58-62.

LAJTHA, A. (1974) Amino acid transport in the brain in vivo and in vitro. In Aromatic Amino Acids in the Brain. CIBA Foundation Symposium 22 (new series) Amsterdam: Elsevier, Excerpta Medica.

Shaw, D. M., Tidmarsh, S. F., Karajgi, B. M. el al (1982). Pilot study of amino acids in senile dementia. British Journal of Psychiatry, 139, 580-582.

\section{Mental Health Act and Medical Treatment Without Consent \\ Dear Sir,}

I thought your readers may be interested in an aspect of the new Mental Health Act which appears extremely illogical.

I have currently on my ward a lady suffering from a severe chronic intractable depression with extreme retardation so that communication with her is impossible. Because of her inability to give valid consent I have already had to have three second opinions from the Mental Health Commission. At the time of the renewal of her Section I was informed by the Commission that if I wished to use any further treatment I would have to get yet a further fourth second opinion. A few days ago this lady appeared to be in pain and appeared to hold her leg in an abnormal posture. Her hip was $\mathrm{X}$-rayed and this revealed a fracture of the acetabulum. My orthopaedic colleagues informed me that operative intervention was unnecessary and that she needed to be treated with analgesia alone as she did appear to be in such discomfort. As this lady was unable to give valid consent and as analgesia could not be constituted as a life saving procedure, I contacted the Commission to provide a second opinion to allow me to prescribe it. I was informed by the Commission that for medical treatment such as this I did not require their opinion even though valid consent could not be obtained. I was told that if in my clinical judgement as a doctor analgesia was necessary then I could prescribe it.

It seems strange to me that I am allowed to make clinical judgements about my patients in nonpsychiatric areas and prescribe medication for them, but I am not allowed to do this in the one field I would consider myself to have some expertise in, namely the management of her depression. Also I wonder if I would be allowed to use antidepressants in this patient without a second opinion, on the basis that there is now considerable evidence that antidepressants have an analgesic effect!

\section{Leicester General Hospital \\ Gwendolen Road \\ Leicester LE5 4PW}

C. J. THOMAS

\section{Transcultural Psychiatry \\ Dear Sir,}

I am delighted that Dr de Pauw (Journal, November 1985, 147, 585-586) thinks I am passionate. Passionate or not, however, I am not responsible for the vagaries of the Comprehensive Textbook of Psychiatry (although if it says two different things in two different places that seems rather comprehensive).

The issue appears to be this: what reliance can be placed on the reports of colonial psychiatrists as to the actual occurrence of certain traditional behaviours variously termed the "culture-bound syndromes"? I am not entirely clear about de Pauw's point: the argument for windigo is in dispute, 
so the problem is solved by suggesting there is an "ethnopharmacological basis" for the zombi, implying the colonial psychiatrist got it right every time.

I was merely saying we have to "examine more closely" the so-called culture-bound syndromes (Journal, July 1985, 147, 93) and pointed out evidence for and against "voodoo death". This is nothing to do with zombis, vodun or even Haiti. It is one of the terms bequeathed to us by European psychiatrists in Africa and Australia, and is perhaps more properly termed psychogenic death.

As to Haiti, Douyon and Wade Davis (1983) do not claim that tetrodotoxin causes people to be "raised in a comatose trance from the grave and forced to toil as a slave". Wade Davis' evidence is that intraperitoneal injections of local poisons into rats produce "catalepsy", and similar symptoms have been noted in diguatera and tetrodotoxin poisoning (as found in the consumption of the Japanese delicacy Fuga pardalis).

The term zombi (and the cognate jumbi as it is called in rural Trinidad where I carried out my fieldwork in traditional medicine) has at different times had a variety of meanings: god (power, orisha), possessed initiate, soul or body, twin, skin disease, mildew and mushroom, let alone reanimated corpse (Thompson 1958, Deren 1970). My own informants offered related ambiguous and binary notions including lesbian (zami). Zombi is probably derived from Amerindiam zemi (twin soul) and is an indigenous psychological term, a rich, complex and subtle web of explanations of personal identity, selfhood, autonomy, action, causality and power. Mircea Eliade has gone so far as to say the term refers to mystical power in general, "the sacred". Interestingly, given the intensive fieldwork in remote areas of Haiti by numerous social anthropologists previously eg Métraux 1959), none came across the mysterious slave corpse beloved of the European imagination.

Apart from questions of scholarship and sensationalism, it may be relevant to emphasise again the dangers of scientism: reducing social patterns and belief to a single unitary biological cause, its "basis" as de Pauw terms it. Social meanings are ascribed to the phenomena of the natural world, whether they are stars, sexes or the dead. Mars (1947) found that one claimed zombi had neurosyphilis.

\section{All Saints Hospital Lodge Road \\ Birmingham B18 5SD}

\section{References}

DEREN, M. (1970). Divine Horsemen: The Living Gods of Haiti. New York: Documentext.

Mars, L. (1947) La Lutte Contre La Folie. Cited in Bouguignon, E. (1985). Response to Wade Davis, Transcultural Psychiatric Research Review, 12, 192-194.

MÉrraux, A. (1959). Voodoo. Oxford: Oxford University Press.

Tномson, R. W. (1958). Mushrooms, umbrellas and black magic: A West Indian Linguistic problem, American Speech, 32 , 130-135.

WADE DAVIS, E. (1983). The Ethnobiology of the Haitian Zombie. Journal of Ethnopharmacology, 9, 85-104.

\section{Phobic Neuroses in India: A Cross-Cultural Comparison \\ DEAR SIR,}

We read with interest Drs. Raguram and Bhide's account of phobic neuroses in India (Journal, November 1985, 147, 557-560). While commenting on the lack of Indian studies specifically on this subject, they fail to mention an earlier report by us (Chambers $e t$ al, 1980) on phobic neuroses from the same institute. Apart from a clinical analysis of 39 phobic subjects seen during the first three years (1976-1979) of the eight years spanning Raguram and Bhide's study, we had carried out a cross-cultural Indo-British comparison of phobic neuroses.

The Indian part of our study was a similar retrospective case record survey of 39 patients ( 31 male and 8 female) diagnosed as having phobic neuroses (ICD-9 criteria) at the National Institute of Mental Health and Neurosciences (NIMHANS), India. The British part of the study involved analysis of case records of a group of 30 similarly diagnosed phobic patients at the Maudsley Hospital, London, UK. The Maudsley comparison group was drawn randomly from a series of 268 phobic patients treated at this hospital between 1972-1976, and matched for age and sex with the Indian group. One of the investigators (J.C.) analysed the case records in both hospitals.

We found that males (79\%) predominated in the Indian group as compared to the British group $(21 \%)$ confirming Raguram and Bhide's finding of a male preponderance in the Indian group. The median ages of presentation, duration of symptoms, social class and marital status did not significantly differ between the two groups.

Thirty-six percent of the Indian sample were graduates as compared to $11 \%$ of the British sample $(P<0.001)$ suggesting that education promotes help-seeking behaviour for phobic patients in the Indian context.

The British sample contained significantly more patients with agoraphobia (Indian group: $27.5 \%$; British group: $60 \%, P<0.05)$ and social phobias 